\title{
Interaction between leptin and leptin receptor in gastric carcinoma: Gene ontology analysis
}

\author{
V. Wiwanitkit \\ Department of Laboratory Medicine. Faculty of Medicine. Chulalongkorn University. Bangkok, Thailand
}

\section{RESUMEN}

El carcinoma gástrico es un cáncer muy poco frecuente pero importante. Se ha postulado que la leptina, una citocina que aparece elevada en las personas obesas, está relacionada con el cáncer. Se sabe que la leptina y su receptor pueden desempeñar un papel positivo en la progresión del cáncer gástrico. Sin embargo, nunca se ha dilucidado el mecanismo exacto al que daría lugar la interacción entre la leptina y el receptor de leptina. Aquí, el autor empleó una nueva tecnología de ontología genética para predecir la función molecular y el proceso biológico resultantes de la interacción entre la leptina y su receptor. Frente a la leptina y su receptor, el compuesto leptina-receptor realiza la misma función y el mismo proceso biológico que el receptor de leptina. Esto puede confirmar que el receptor de leptina ejerce un importante efecto supresor sobre la expresión de leptina. Pueden observarse una pérdida de actividad hormonal y la alteración de la vía normal de señalización celular de la leptina. El bloqueo de este receptor podría constituir una estrategia terapéutica racional.

Palabras clave: Leptina. Receptor. Carcinoma gástrico.

\begin{abstract}
Gastric carcinoma is a rare but important malignancy. The link between leptin, a cytokine that is elevated in obese individuals, and cancer development has been proposed. It is noted that leptin and its receptor may play a positive role in the progression in gastric cancer. However, the exact mechanism resulting form the interaction between leptin and leptin receptor has never been clarified. Here, the author used a new gene ontology technology to predict the molecular function and biological process due to the interaction between leptin and leptin receptor. Comparing to leptin and leptin receptor, the leptin-leptin receptor poses the same function and biological process as leptin receptor. This can confirm that leptin receptor has a significant suppressive effect on the expression of leptin. Loss of hormone activity and disturbance of normal cell signaling pathway of leptin can be seen. Blocking of receptor might be rational therapeutic strategy.
\end{abstract}

Key words: Leptin. Receptor. Gastric carcinoma.

Wiwanitkit $V$. Interaction between leptin and leptin receptor in gastric carcinoma: gene ontology analysis. Rev Esp Enferm Dig 2007; 99: 201-205.

\section{INTRODUCTION}

Gastric cancer is often discovered incidentally with late complication (1). The prognosis for gastric cancer is poor and, in most industrialised countries, the survival is

Received: $15-11-06$.

Accepted: 26-02-07.

Correspondence: Viroj Wiwanitkit. Department of Laboratory Medicine. Faculty of Medicine,. Chulalongkorn University. Bangkok Thailand 10330. e-mail:wviroj@pioneer.netserv.chula.ac.th only $10 \%$ after 5 years from diagnosis (2). The most recent estimates of global cancer incidence indicate that in 1990 stomach cancer was the second most frequent cancer in the world after lung cancer with about 800,000 new cases diagnosed every year (3). While surgical approaches are curative in 70 to $95 \%$ of cases when cancer does not invade beyond the submucosal, 5-year survival is poor in patients with more advanced gastric cancer (4). Gastric cancer is the second most common cause of death from cancer worldwide (5). While surgical approaches are generally curative when the disease is confined to the gastric, a number of cases that present in the metastatic form and require conventional medical therapy are asso- 
ciated with a truly dismal patient survival rate (1). Recently, several novel and promising therapeutic approaches to gastric carcinoma are emerging.

The link between leptin, a cytokine that is elevated in obese individuals, and cancer development has been proposed (6). Leptin is also mentioned for the clinical correlation for gastric cancer. Recently, Ishikawa et al. performed a study to examine the expression of leptin and its receptor in normal gastric mucosa and neoplasia (7). They found that the expression levels of both leptin and it receptor tended to increase as the depth of tumor invasion or TMN stage increased (7). They proposed that overexpression of leptin and its receptor may play a positive role in the progression in gastric cancer (7). However, the exact mechanism resulting form the interaction between leptin and leptin receptor has never been clarified.

To study the interaction between two proteins is hard. Luckily, the new development in bioinformatics can be applied in nanoscale genomics and proteomics research. Here, the author used a new gene ontology technology to predict the molecular function and biological process due to the interaction between leptin and leptin receptor.

\section{MATERIALS AND METHODS}

\section{Getting the sequence}

The database Pubmed was used for data mining of the amino acid sequence for leptin and leptin receptor.

\section{Prediction of molecular function and biological process}

The author performs prediction of molecular function and biological process of leptin, leptin receptor as well as combination between leptin and leptin receptor using a novel gene ontology prediction tool, GoFigure (8). GoFigure is an computational algorithm tool which is recently developed in gene ontology (8). The tool accepts an input DNA or protein sequence, and uses BLAST to identify homologous sequences in gene ontology annotated databases (8). In this work, the sequences of leptin, leptin receptor and leptin-leptin receptors are used as input. The approach is to use a BLAST search to identify homologs in public databases that have been annotated with gene ontology terms (8). These include: SwissProt, Flybase (Drosophila), the Saccharomyces Genome Database (SGD), Mouse Genome Informatics (MGI) and Wormbase (nematode) (8). The contents of the results will show results for molecular function as well as biological process of the studied protein (8). The prediction of molecular function and biological process were presented and compared.

\section{RESULTS}

From searching of the database PubMed, sequence of leptin and leptin receptor were derived. Using GoFigure server, the molecular function and biological process in leptin, leptin receptor as well as leptin-leptin receptor (the complex formed after binding leptin to its receptor) are predicted. The predicted biological processes of leptin, leptin receptor and leptin-leptin receptor are shown in figures 1,2 and 3, respectively. The molecular function and biological processes of in leptin and leptin receptor are similar as presented in table I. The function and biological process of leptin and leptin-leptin receptor are same.

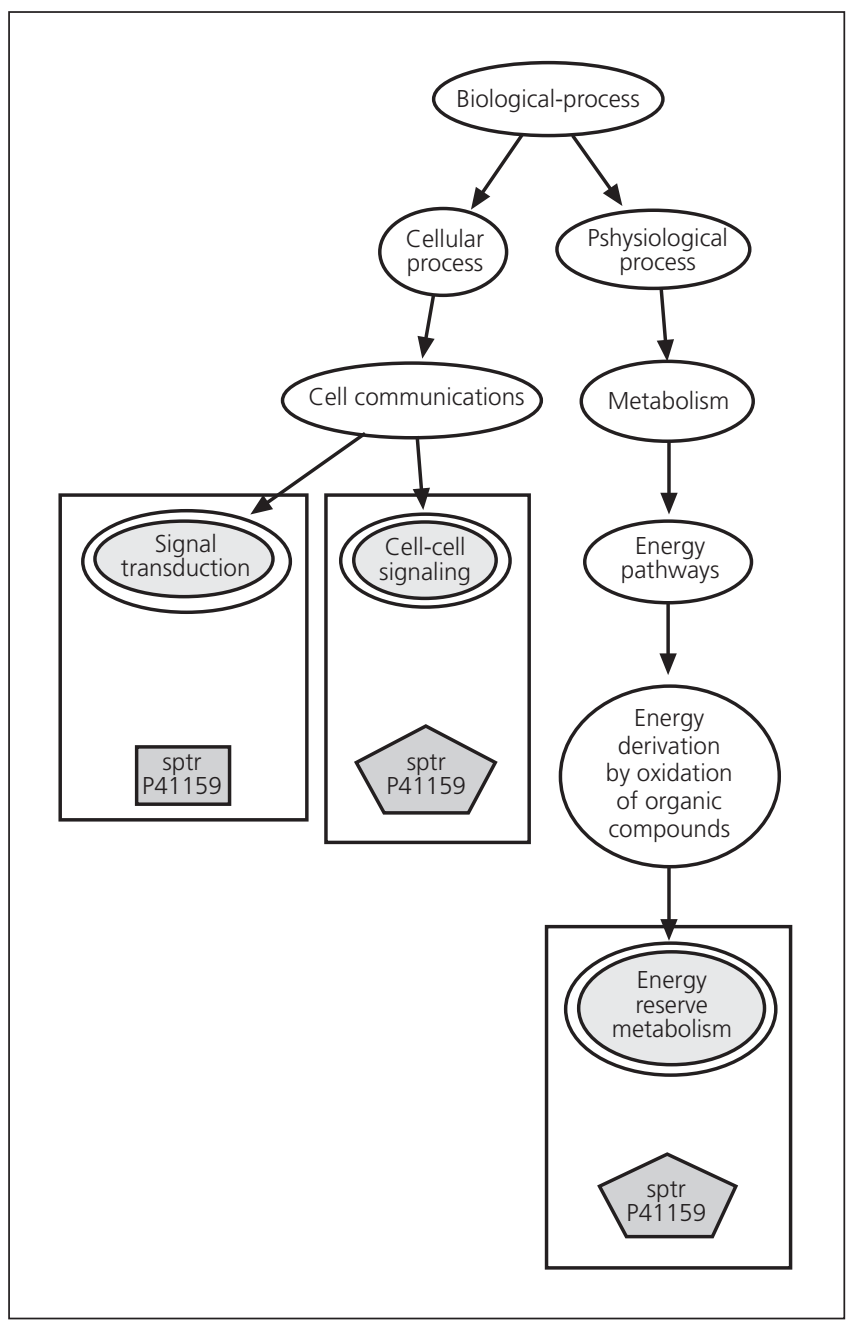

Fig. 1. Expected biological process of leptin.

\section{DISCUSSION}

Presently, therapy for advanced gastric carcinoma is ineffective in the majority of patients. New developments have forced a re-evaluation of our understanding 


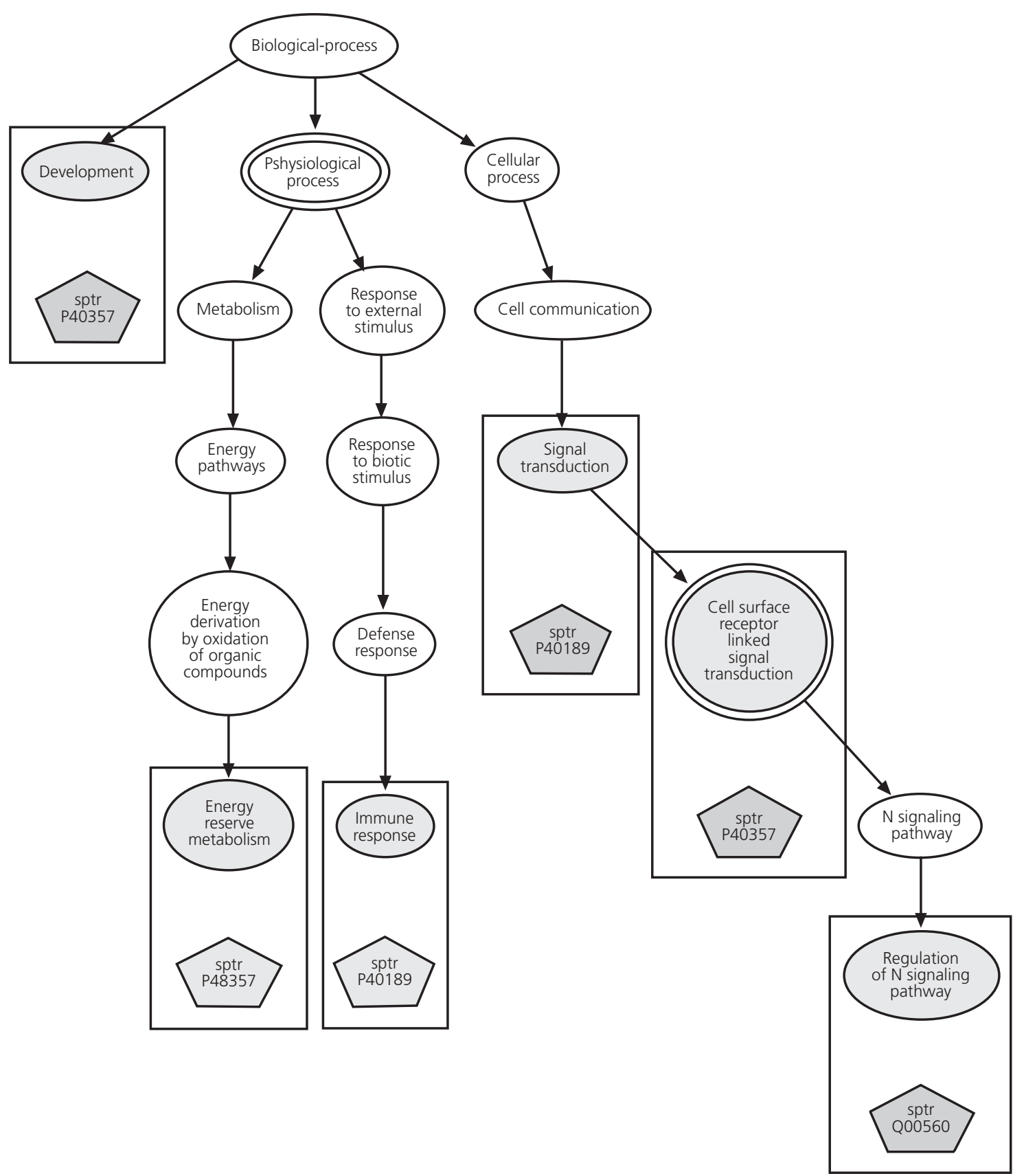

Fig. 2. Expected biological process of leptin receptor.

for diagnosis and treatment of gastric carcinoma. Leptin is an important regulator of food intake and energy expenditure (9). Leptin and leptin receptors are expressed in human gastric mucosa (9). Initially it was thought to be expressed exclusively in and secreted by adipocytes (9). Leptin is a focus on the pathogenesis of cancer (7). Basically, leptin is known to act as a growth factor through the Janus-activated kinase (JAK)/signal transducer and activator of transcription signaling pathway as well as the mitogen-activated protein kinase pathway (10). Interaction between leptin and leptin receptor is believed to be an important factor inducing the gastric carcinogenesis (7). The presence of an autocrine loop of leptin system in the development of intestinal-type gastric adenocarcinoma was recently reported by Zhao et al. (11). To access the interaction between leptin and leptin receptor is therefore useful for gastric carcinoma management. 


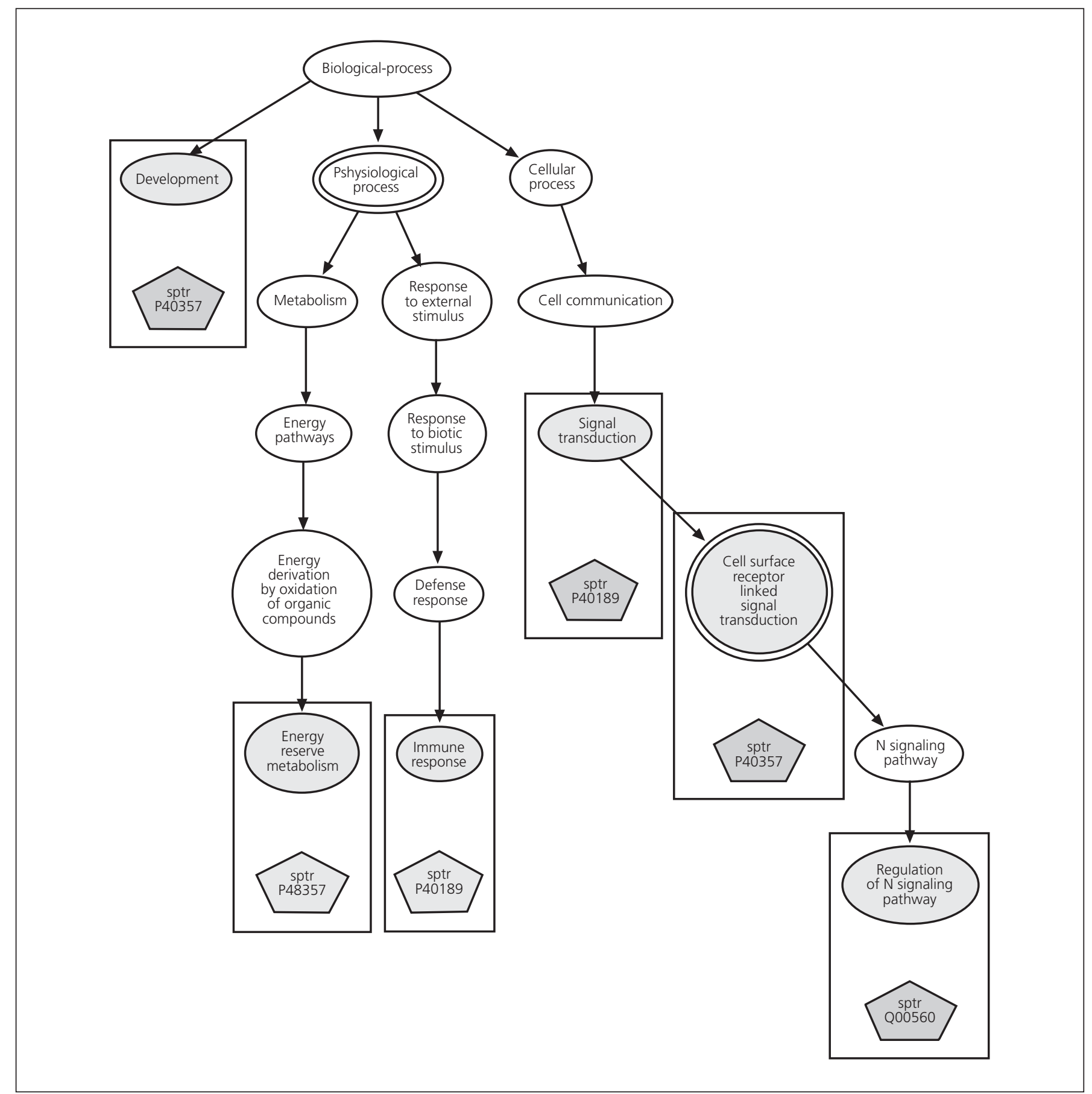

Fig. 3. Expected biological process of leptin-leptin receptor.

Based on the recent advance in the genomics technology, current microarray technologies permit the examination of gene expression patterns of tens of thousands of genes (8). At present, a rapid means to get some idea of potential function of a gene product is to obtain the ontology terms that describe the gene (8). The gene ontology is developed for this specific purpose. Here, the author used a gene ontology tool to predict the function aberration due to the interaction between leptin and leptin receptor.
Comparing to leptin and leptin receptor, the leptin-leptin receptor poses the same function and biological process (Figs. 2 and 3) as leptin receptor. After binding to leptin receptor, leptor losses its hormonal activity and cell-cell signaling process (Table I). Although the derived leptin-leptin receptor complex has larger molecular size than leptin receptor, the complex has the same function and process as leptin receptor according to the prediction. This is very interesting since leptin is a ligand which is 
Table I. The summary on the molecular function and biological process of leptin, leptin receptor as well as leptinleptin receptor

\begin{tabular}{lll}
\hline & Molecular function & Biological process \\
\hline Leptin & 1. Protein binding & 1. Signal transduction \\
& 2. Hormone activity & 2. Cell-cell signaling \\
& 3. Energy reserve metabolism \\
\hline leptin receptor & 1. Oncostatin M receptor activity & 1. Signal transduction \\
& 2. Interleukin - 6 receptor activity & 2. Immune response \\
& 3. Transmembrane receptor activity & 3. Development \\
& 4. Protein binding & 4. Energy reserve metabolism \\
& & 5. Regulation of N signaling \\
& pathway \\
\hline Leptin-leptin receptor & 1. Oncostatin M receptor activity & 1. Signal transduction \\
& 2. Interleukin-6 receptor activity & 2. Immune response \\
3. Transmembrane receptor activity & 3. Development \\
4. Protein binding & 4. Energy reserve metabolism \\
& 5. Regulation of N signaling \\
& pathway \\
\hline
\end{tabular}

generally has biological functions after binding to its receptor. Direct effect of leptin without binding to its receptor is rarely mentioned. In this work, the prediction can confirm that leptin poses its direct effect. This work can also confirm that leptin receptor has a significant suppressive effect on the expression of leptin. Loss of hormone activity and disturbance of normal cell signaling pathway of leptin can be seen. Yang et al. recently proposed that leptin receptor might modulate the actions of leptin in tissues in which direct action of leptin has been demonstrated (12). Yang et al. found that in settings in which leptin and its receptor coexisted, leptin receptor might sequester leptin from productive interactions with OB-R mRNA (12). Indeed, a recent study by Pai et al. on the leptin and its receptor indicated that leptin might be produced and act locally in a paracrine or autocrine manner for gastric cancer (13). They also indicated that leptin might promote cancer growth by activating multiple signaling pathways (13). However, the results from this study described the different process. It seems that the regulation of $\mathrm{N}$ signaling pathway is from leptin receptor not leptin (Table I). However, blocking its action at the receptor level as a rational therapeutic strategy is the common conclusion. Further experimental studies are needed before making a conclusion on this topic. The finding in this study is not only supports the previous knowledge on leptin but also gives the new view on the pathogenesis of gastric carcinoma.

\section{REFERENCES}

1. Medina-Franco H. Gastric cancer. Rev Gastroenterol Mex 2006; 71 (Supl. 1): 28-30.

2. Pellicano R, Mladenova I, Martinotti R, Fagoonee S, Rizzetto M. Gastric cancer and Helicobacter pylori: An interdisciplinary point of view. Minerva Med 2006; 97: 31-8

3. Plummer M, Franceschi S, Munoz N. Epidemiology of gastric cancer. IARC Sci Publ 2004; (157): 311-26.

4. Hundahl S, Phillips J, Menck H. The National Cancer Data Base Report on poor survival of US gastric carcinoma in patients treated with gastrectomy. Cancer 2000; 88: 921.

5. Pisani P, Parkin DM, Bray F, Ferlay J. Estimates of the worldwide mortality from 25 cancers in 1990. Inter J Cancer 1999; 83: 18-29.

6. Garofalo C, Surmacz E. Leptin and cancer. J Cell Physiol 2006; 207 12-22.

7. Ishikawa M, Kitayama J, Nagawa H. Expression pattern of leptin and leptin receptor (OB-R) in human gastric cancer. World J Gastroenterol 2006; 12: 5517-22.

8. Khan S, Situ G, Decker K, Schmidt CJ. GoFigure: automated Gene Ontology annotation. Bioinformatics 2003; 19: 2484-5.

9. Shida D, Kitayama J, Mori K, Watanabe T, Nagawa H. Transactivation of epidermal growth factor receptor is involved in leptin-induced activation of janus-activated kinase 2 and extracellular signal-regulated kinase $1 / 2$ in human gastric cancer cells. Cancer Res 2005; 65: 9159-63.

10. Mix H, Widjaja A, Jandl O, Cornberg M, Kaul A, Goke M, et al. Expression of leptin and leptin receptor isoforms in the human stomach. Gut 2000; 47: 481-6.

11. Zhao L, Shen ZX, Luo HS, Shen L. Possible involvement of leptin and leptin receptor in developing gastric adenocarcinoma. World J Gastroenterol 2005; 11: 7666-70.

12. Yang G, Ge H, Boucher A, Yu X, Li C. Modulation of direct leptin signaling by soluble leptin receptor. Mol Endocrinol 2004; 18: 1354 62.

13. Pai R, Lin C, Tran T, Tarnawski A. Leptin activates STAT and ERK2 pathways and induces gastric cancer cell proliferation. Biochem Biophys Res Commun 2005; 331: 984-92. 